\title{
Late Quaternary vegetation dynamics from central parts of the Madeira River in Brazil
}

\author{
Yuri Oliveira Feitosa ${ }^{1,6}$, Maria Lúcia Absy ${ }^{1,2}$, Edgardo Manuel Latrubesse ${ }^{3,4}$ and José Cândido Stevaux ${ }^{4,5}$
}

Received: August 7, 2014. Accepted: October 3, 2014

\begin{abstract}
The present study reconstructs the paleovegetation of a varzea (seasonally flooded) forest in the central parts of the Madeira River floodplain in Brazil using palynological data. Forty-nine cut-bank sediment samples from the Madeira River were processed in the study; from these, ten samples contained pollen: two contained pollen from the Middle Pleniglacial age, one contained pollen from the Tardiglacial age, six contained pollen from the Holocene, and one contained more recently deposited pollen. The Middle Pleniglacial pollen belonged to a primary succession varzea forest, while the Tardiglacial pollen represented a late succession varzea forest. On the other hand, the three Holocene samples showed the characteristic composition of chavascal (water-logged forest) or lacustrine varzea forest, and three samples belonged to a late succession varzea forest. The most recent pollen deposit represented a secondary succession varzea forest. This paleovegetation showed a typical mosaic distribution, which may be explained by the fluvial dynamics, high species richness and diversity in the varzea forest, and the presence of dominant species.
\end{abstract}

Keywords: Cut-bank sediment, late Pleistocene-Holocene, palynology, southern Amazonian tributary, varzea

\section{Introduction}

Palynological studies have played a crucial role in the reconstruction of past vegetation (Absy et al. 1991; Hoorn 1997; Mayle et al. 2000; Colinvaux et al. 2001; D’Apolito et al. 2013). However, there are still large gaps in palynological and past vegetation knowledge at different scales. In particular, vast areas of the Amazon region remain unexplored, although several vegetation maps for the last glacial period have been constructed despite this deficiency (Hammen \& Absy 1994; Bush 1994; Hooghiemstra \& Hammen 1998; Haberle \& Maslin 1999; Thomas 2000; Cowling et al. 2001; Anhuf et al. 2006). These maps show a clear trend of forest retreat following a decrease in rainfall; however, most palynological studies have been conducted in "terra firme" (non-flooded) forests. On the other hand, studies including Quaternary fluvial records have suggested that the Amazon basin experienced a series of paleohydrological changes during the last glacial period (Latrubesse 2003; Latrubesse et al. 2005).

The flooded areas within the Amazon basin extend over an area of approximately $30 \%$ of the total basin area and include seasonally flooded areas, permanently flooded areas, river mouth areas, and occasionally flooded areas (Junk et al. 2011). From these, varzea forests are seasonally flooded by white-water rivers rich in nutrients (Prance 1979) and present the highest plant species richness among all flooded forests worldwide (Wittmann et al. 2006); however, little is known of its paleovegetation. Thus, sediments of alluvial terraces from the areas of varzea forest have been collected to reconstruct the vegetation from palynological records for the Amazon River near Manaus, Terra Nova in the Careiro Island, and Caquetá River in the Columbian Amazon (Absy 1979; Hammen et al. 1992).

The Madeira River is the world's fourth largest in liquid flow with a drainage basin of $1,300,000 \mathrm{~km}^{2}$ (Latrubesse 2008). It is the most important tributary of the Amazon River, accounting for $15 \%$ of the Amazon's discharge and providing the greatest contribution of suspended sediments (Goulding et al. 2003, Latrubesse et al. 2005; Filizola \& Guyot 2009). Despite the regional importance of the Madeira River, few paleoecological studies have been conducted on this region. Geological (Latrubesse 2002) and palynological (Absy \& Hammen 1976; Hammen \& Absy 1994) evidence have showed that the Late Quaternary regional climate was characterized by a series of drier periods. To this end, paly-

\footnotetext{
${ }^{1}$ Programa de Pós-graduação em Ecologia, Instituto de Pesquisa da Amazônia, Manaus, AM, Brasil

${ }^{2}$ Instituto Nacional de Pesquisas da Amazônia, Coordenação de Biodiversidade, Laboratório de Palinologia, Manaus, AM, Brasil

${ }^{3}$ The University of Texas at Austin, Department of Geography and Environment

${ }^{4}$ Universidade Estadual Paulista Campus Rio Claro, Instituto de Geociências e Ciências Exatas/IGCE

${ }^{5}$ Universidade Estadual de Maringá, Maringá, PR, Brasil

${ }^{6}$ Author for correspondence: yfeitosa@gmail.com
} 
nological evidence from fluvial sediments could provide a more direct reconstruction of the vegetation in the Madeira River region during this period; however, such studies, particularly regarding the Madeira River floodplain have not yet been conducted.

This study aims to reconstruct the paleovegetation of the varzea forest in the central parts of the Madeira River floodplain through palynological analyses and radiocarbon ${ }^{14} \mathrm{C}$ dating from alluvial terrace sediments of the river to contextualise the region within the Amazonian paleoecological setting.

\section{Study area}

The study area is located between the cities of Porto Velho and Huimatá (Fig. 1). It presents a characteristic tropical monsoon climate (Am, according to Köppen's climate classification), an average annual temperature of $28^{\circ} \mathrm{C}$, and an average rainfall of 2,500-3,000 mm/year (DNPM 1978).

The Madeira River originates in Bolivia from the confluence of the Guaporé, Mamoré, Beni, and Madre de Dios rivers. Approximately $50 \%$ of the Madeira River drainage basin is located in Peru (10\%) and Brazil (40\%). The river drains the Andes Mountain Range, Brazilian Shield, and Amazon Floodplain (Goulding et al. 2003; Filizola \& Guyot 2009) and develops into a meandering-channel fluvial pattern within the Brazilian territory (Latrubesse 2008; 2012).

\section{Materials and methods}

A total of 49 samples from 22 locations were collected from cut banks of different morphostratigraphic units along the Madeira River (sediments from different fluvial terraces; Fig. 1). The material preparation complied with the following phases: sample treatment for 10 minutes in a $10 \%$ aqueous solution of potassium hydroxide $(\mathrm{KOH})$ (Faegri \& Iversen 1966), followed by acetolysis (Erdtman 1960) and gravity separation using a bromoform-alcohol mixture at a density of 2.0" (Kummel \& Raupp 1965). After gravity separation, the residual material was mounted on glycerinated gelatine slides for optical microscope analysis.

After preparing the slides, the microscopic analysis showed that only 10 samples contained pollen. A total of 300 pollen grains were counted in each analysed sample. Simultaneously, pterydophytae spores were counted stopping when a total of 300 pollen grains was reached. Pteridophyte spores were separated into different morphotypes and identified when possible. To estimate pollen concentration, we added a known number of spores of the exotic species Lycopodium clavatum (Stockmar, 1971) to the sample; however, the low number of Lycopodium spores subsequently found in the samples made it impossible to accurately estimate pollen concentration. Pteridophyte spores were not included in the pollen sum. They were separated into different morphotypes, and the percentage of each type of

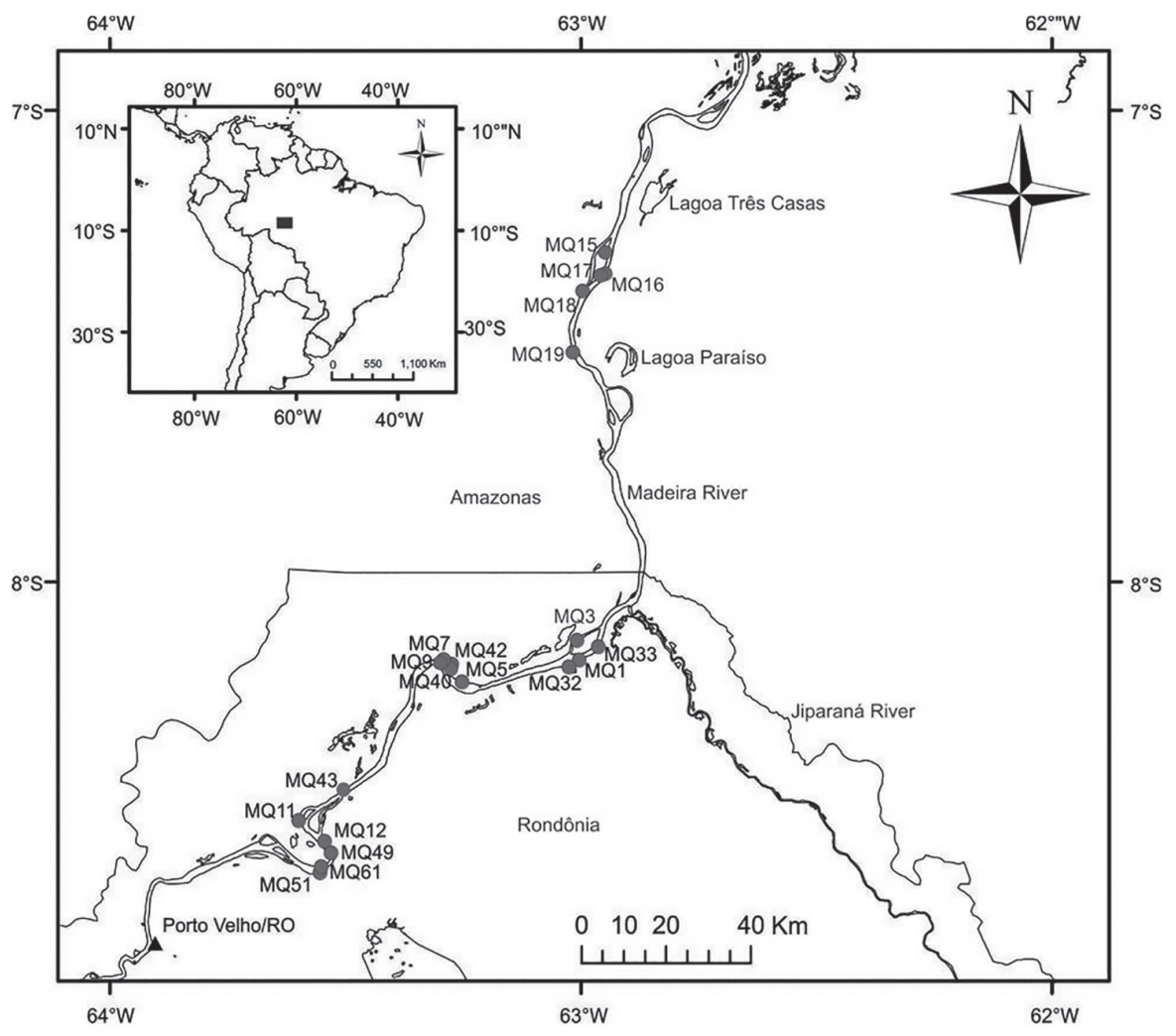

Figure 1: Study area and location where the samples were collected. Location MQ 19 falls within Humaitá city boundaries. 
spore was calculated from the sum of pollen. These data were used to draw a pollen diagram for all the study sites whose samples contained pollen.

All pollen was additionally characterized according to type, based on morphological entities encompassing one or more species as taxonomic entities (Joosten \& Klerk 2002; Klerk \& Joosten 2007). Pollen types were identified from illustrations and descriptions from studies published by Absy (1979), Hooghiemstra (1984), and Roubik \& Moreno (1991), and through a comparison with the reference collections held by the Laboratory of Palynology at the National Institute for Amazonian Research (Instituto Nacional de Pesquisas da Amazônia, INPA).

Because the samples are spread over different morphostratigraphic units of the Madeira River, the palynological data obtained are also distributed over time and space. Palynological researches generally focused on a single point and describe how the vegetation on site changed over time. In this case, it is not possible to adopt this methodology, because the differences found between the results of these samples can be derived from different times and places. Therefore, we focused on the description of the vegetation structure. Species dominance is one of the most important structural characteristics in tropical forests (Hart et al. 1989). Here we aimed to describe species dominance in the paleovegetation present in the study area; to this end, pollen types were classified according to their frequencies as follows: dominant pollen (>45\%), accessory pollen ( $15 \%$ $\leq 45 \%)$, rare pollen $(3 \% \leq 15 \%)$, and sporadic pollen $(<3 \%)$, following the categories for melissopalynology proposed by Louveaux et al. (1978).

The Shannon-Weiner diversity index $(\mathrm{H})$ was used to characterise the diversity of the different pollen types. To calculate $\mathrm{H}$, pollen types were grouped into genus whenever possible; however, for families such as Poaceae, Cyperaceae and Moraceae whose identification to genus level is difficult, the types were grouped at the family level. These data was analyzed using un-weighted pair group method with arithmetic mean (UPGMA) analysis.. To minimize the noise, sporadic pollen types from all samples were excluded from the analysis. In addition, the raw data matrix was square root transformed. Cluster analysis, along the pollen diagram and the classification of pollen types based on their frequencies, were used to differentiate the vegetation represented in the pollen record.

The description of paleovegetation of the varzea forest in the central region of the Madeira River followed that of Wittmann et al. (2010), which at the same time was based on Worbes et al. (1992) and Ayres (1993), with additional data by Schöngart et al. (2003) and Wittmann et al. (2002; 2004). The aforementioned studies were focused on the central Amazon varzea forests of the Amazon-Solimões River; however, due to the lack of studies focused on varzea forest vegetation of the Madeira River, we adopted these concepts for this study.

Furthermore, samples were selected for analysis by radiocarbon ${ }^{14} \mathrm{C}$ (Tab. 1) at the Centre for Applied Isotope Studies (CAIS, University of Georgia) and Beta Analytic Laboratory. All sample ages were calibrated using the INTCAL13/MARINE13 dataset (Reimer et al. 2013).

\section{Results}

Among the 49 samples processed, only 10 samples from 8 different locations contained pollen (Tab. 2). The cluster analysis showed four different groups of samples (Fig. 2). These results, together with the pollen diagram (Fig. 3) and the classification of pollen types, allowed us to differentiate the following types of varzea forest: primary succession varzea forest, secondary succession varzea forest, late succession varzea forest, and lacustrine varzea forest or chavascal (Tab. 3).

Location MQ 7 showed a profile with seven lithostratigraphic units (Fig. 4). From this location, we processed samples MQ 7(1), MQ 7(2), MQ 7(4), and MQ 7(5) although pollen was observed only in sample MQ 7(2). Sample MQ $7(2)$ was from a unit presenting medium gray mud with plane-parallel wavy lamination and sandy inter-layers. Its estimated age was 36,335-34,750 cal ka BP. The sample did not present a dominant pollen type, and Moraceae and Symmeria appeared as accessory pollen types. This pollen record suggested the presence of a primary succession varzea forest.

At the location MQ 42, only the MQ 42(1) sample was processed, and its age was estimated to be 28,685-28,195 cal ka BP. Its profile presented four lithostratigraphic units (Fig. 4). The sample was specifically collected was clayey-sandy,

Table 1. Radiometric dating $\left({ }^{14} \mathrm{C}\right.$ AMS) of cut-bank samples from the middle Madeira River.

\begin{tabular}{ccccc}
\hline Sample & Dated material & Conventional Age $\left({ }^{14}\right.$ C years BP) & Calibrated Age (cal year BP) & Laboratory Number \\
\hline MQ 3(1) & Wood & $3,710 \pm 20$ & $2,131-2,085$ & CAIS - 11644 \\
MQ 5(4) & Wood & $4,350 \pm 25$ & $3,001-2,993$ & CAIS - 11645 \\
MQ 7(2) & Sediment & $33,250 \pm 210$ & $28,685-28,195$ & Beta - 377672 \\
MQ 11(3) & Wood & $2,460 \pm 20$ & $536-527$ & CAIS - 11646 \\
MQ 32(1) & Wood & $120 \pm 20$ & $1,711-1,719$ & CAIS - 114221 \\
MQ 42(1) & Sediment & $26,050 \pm 100$ & $36,335-34,750$ & Beta-377673 \\
\hline
\end{tabular}


Table 2. Location and processed samples.

\begin{tabular}{ll}
\hline Location & \multicolumn{1}{c}{ Processed samples } \\
\hline MQ 1 & MQ (1) \\
MQ 3 & MQ 3(1), MQ 3(2), MQ 3(3), MQ 3(4), MQ 3(5) \\
MQ 5 & MQ 5(1), MQ 5(2), MQ 5(3), MQ 5(4) \\
MQ 7 & MQ 7(1), MQ 7(2), MQ 7(4), MQ 7(5) \\
MQ 9 & MQ 9(1), MQ 9(2) \\
MQ 11 & MQ 11(1), MQ 11(2), MQ 11(3), MQ 11(4), MQ 11(5), \\
MQ 12 & MQ 12(1), MQ 12(4), MQ 12(5), MQ 12(6) \\
MQ 15 & MQ 15(1) \\
MQ 16 & MQ 16(1), MQ 16(2) \\
MQ 17 & MQ 17(2) \\
MQ 18 & MQ 18(1), MQ 18(5) \\
MQ 19 & MQ 19(1), MQ 19(2) \\
MQ 32 & MQ 32(2) \\
MQ 33 & MQ 33(1), MQ 33(3) \\
MQ 40 & MQ 40(1) \\
MQ 42 & MQ 42(1) \\
MQ 43 & MQ 43(1), MQ 43(2), MQ 43(3) \\
MQ 49 & MQ 49(1), MQ 49(2), MQ 49(3), MQ 49(5) \\
MQ 51 & MQ 51(7), MQ 51(8) \\
MQ 61 & MQ 61(3) \\
\hline
\end{tabular}

Pollen occurred in the samples in bold.

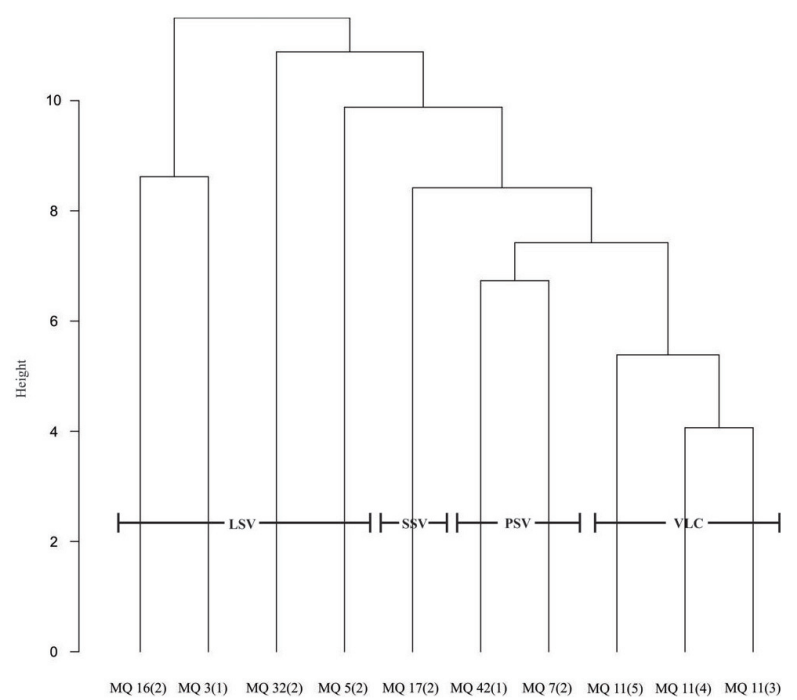

Figure 2. Cluster analysis using Un-weighted Pair Group Method with Arithmetic Mean (UPGMA) analysis. PSV: primary succession varzea; SSV: secondary succession varzea; LSV: Late succession varzea; VLC: lacustrine varzea forest or chavascal.

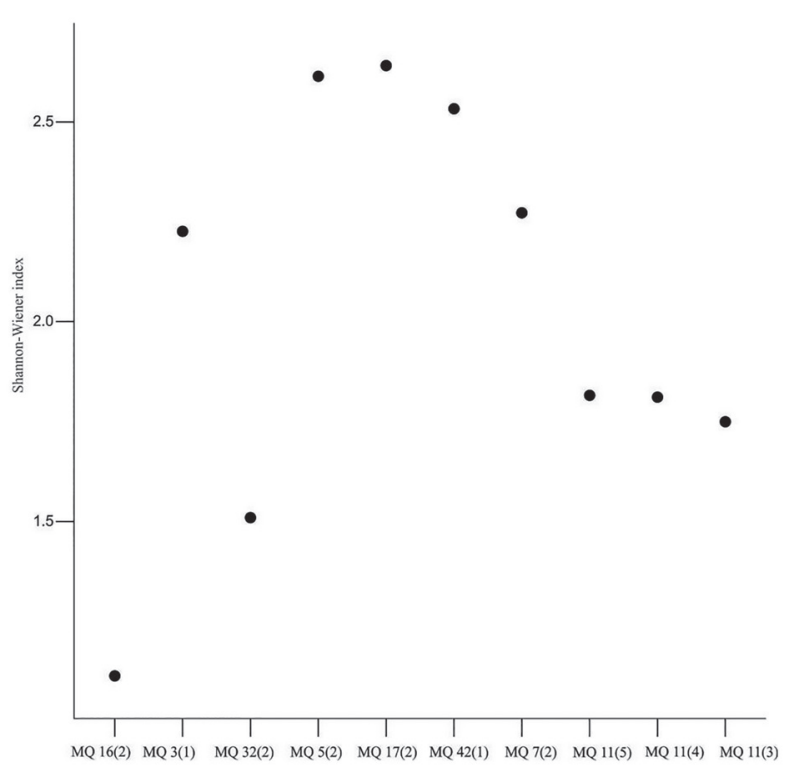

Figure 3. Shannon diversity index of the samples containing pollen.

yellow-cream, laminated, and rippled silt unit. Cyperaceae and Poaceae pollen types appeared as accessory pollen, and no dominant pollen type occurred in MQ 42(1). This pollen assemblage suggested the presence of as primary succession varzea forest on this location in the past.

MQ 16 was located in a morphostratigraphic unit intermediate between a recent plain during the Holocene and a Late Pleistocene unit possibly from the Tardiglacial period. However, further information is required to confirm the age of the unit. From this location, we processed samples MQ 16(1) and MQ 16(2), although we only found pollen in sample MQ 16(2). The profile of this location showed three lithostratigraphic units (Fig. 4); MQ 16(2) was collected from a unit consisting of very fine and muddy sand with incipient lamination and apparent fluidisation, showing the characteristics of a channel. Sapium was the dominant pollen type and Ilex appeared as accessory pollen in the sample. This assemblage suggested the presence of a late succession varzea forest on this location.

Three samples were processed in location MQ 5: MQ 5(1), MQ 5(2), and MQ 5(3); however, we only found pollen in MQ 5(2). The profile of this location presented four lithostratigraphic units (Fig. 4); MQ 5(2) was collected from a unit consisting of dark gray massive clay rich in leaves and trunks. Moraceae appeared as accessory pollen, and no dominant pollen was detected. This assemblage suggested the presence of a late succession varzea forest on this location. Sample MQ 5(4) was not processed for palynological analysis and used for radiocarbon dating. The age of this sample was estimated to be 3,001-2,993 cal ka BP.

In the MQ 32 location, only MQ 32(2) was processed for palynological analyses. This location presented two lithostratigraphic units, a point bar and scroll bar sequence (Fig. 4). MQ 32(1) was chosen for radiocarbon dating and was collected from a height of $7 \mathrm{~m}$. Its age was estimated 
Table 3. Vegetation types present in the pollen record of the Madeira River, vegetation characteristics and dominant and accessory pollen

\begin{tabular}{llll}
\hline \multicolumn{1}{c}{ Vegetation } & \multicolumn{1}{c}{ Samples } & \multicolumn{1}{c}{ Paleovegetation } & \multicolumn{1}{c}{ Dominant and accessory pollen } \\
\hline Primary succession forest & MQ 7(2), MQ 42(1) & $\begin{array}{l}\text { Open with monospecific } \\
\text { groups of pioneer trees } \\
\text { Low density with early } \\
\text { stratification processes }\end{array}$ & $\begin{array}{l}\text { Cyperaceae, Moraceae, } \\
\text { Poaceae and Symmeria }\end{array}$ \\
Late succession forest & MQ 17(2) & $\begin{array}{l}\text { Mell stratified, high species } \\
\text { diversity and richness }\end{array}$ & $\begin{array}{l}\text { Moraceae, Ilex, Sapium and } \\
\text { Euphorbiaceae type 1 }\end{array}$ \\
Varzea forest of lake or chavascal & MQ 5(2), MQ 16(2), MQ & Alchornea, Cyperaceae and Moraceae \\
\hline
\end{tabular}
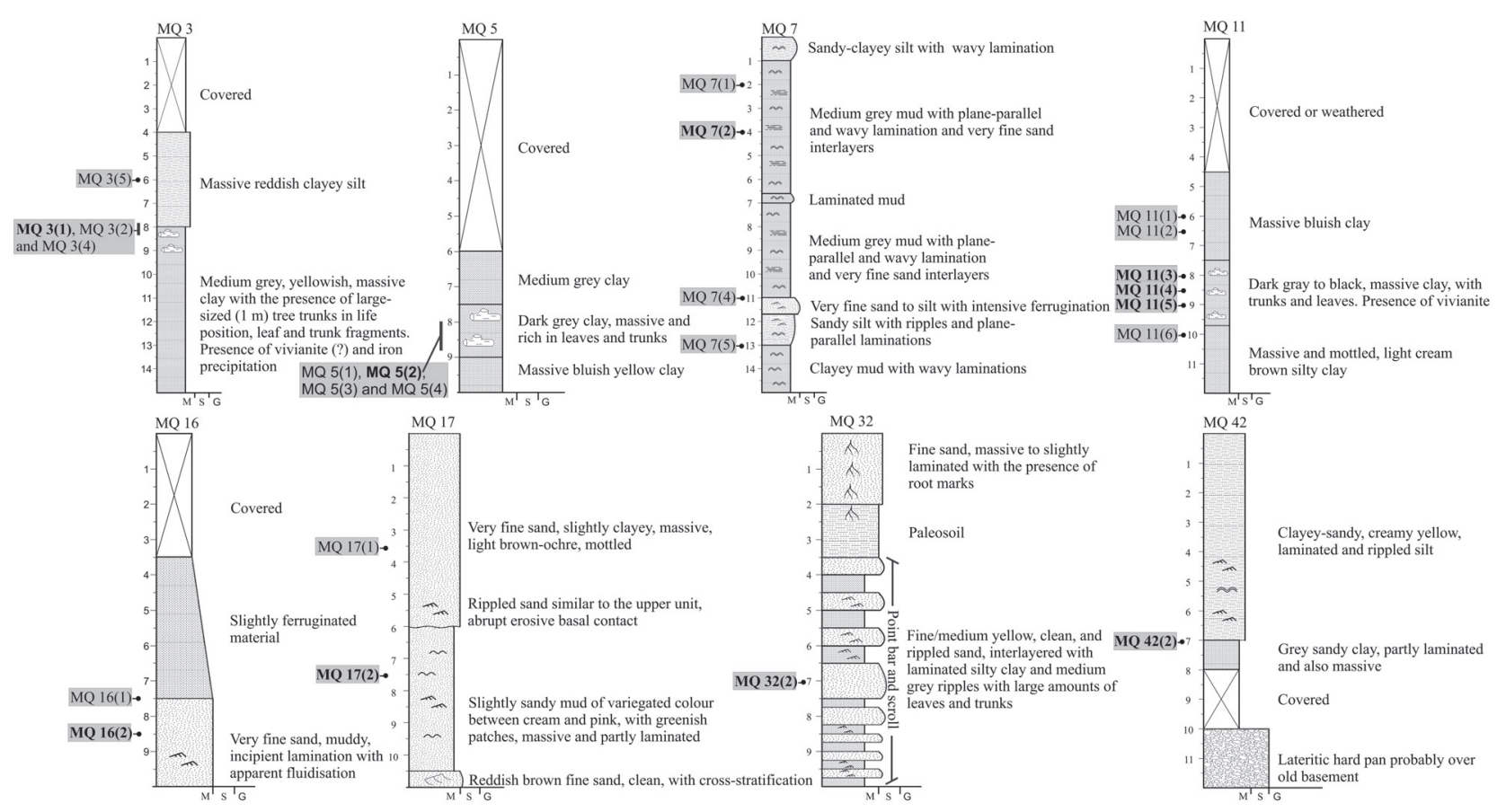

Figure 4: Profiles of the locations including samples containing pollen.

to be $667-686 \mathrm{cal} \mathrm{ka}$ BP; however, this sample was not processed for palynological analysis. Euphorbiaceae type1 pollen was the dominant type in the MQ 32(2) sample, and Moraceae appeared as accessory pollen. The pollen assemblage found in MQ 32(2) suggested the presence of a late succession varzea forest.

Location MQ 3 showed three lithostratigraphic units (Fig. 4). Five samples were processed from this location: MQ 3(1), MQ 3(2), MQ 3(3), MQ 3(4) and MQ 3(5). Pollen was only found in MQ 3(1), which was collected from the top of a unit consisting of a medium gray, yellow, massive clay with largesized $(1 \mathrm{~m})$ trunks in life position, leaves, and trunk fragments. We also found iron precipitates and the possible presence of vivianite. Sapium appeared as accessory pollen in MQ 3(1), and no dominant pollen was found. The pollen record could be interpreted as a late succession varzea forest; in addition, MQ 3(1) had an estimated age of 2,131-2,085 cal ka BP.
Regarding location MQ 11, samples MQ 11(1), MQ 11(2), MQ 11(3), MQ 11(4), MQ 11(5), and MQ 11(6) were processed. Pollen was found in samples MQ 11(3), MQ 11(4), and MQ 11(5), which were collected from a unit with dark gray to black massive clay with trunks and leaves, with traces of vivianite (Fig. 4). MQ 11(3) had an approximate age of 536-527 cal ka BP and included grains of Cyperaceae and Moraceae as accessory pollen and no obvious dominant pollen type. In MQ 11(4), Cyperaceae pollen type was the dominant pollen, and no accessory pollen type was found. Alchornea and Cyperaceae were the accessory pollen types present in MQ 11(5), which showed no dominant pollen type. The pollen assemblage described from samples MQ 11(3), MQ 11(4), and MQ 11(5) suggested the presence of a lacustrine varzea forest or a chavascal type of vegetation.

Location MQ 17 occurred in a recent morphostratigraphic unit possibly from the Holocene. This location 
showed three lithostratigraphic units (Fig. 4). Only one sample, MQ 17(2), was processed, collected from a unit that exhibited gray, laminated, muddy sand with undulations and fluidisation feature sand, possibly trough-cross bedded. Melastomataceae pollen appeared as accessory pollen, and no dominant pollen was found. The pollen assemblage found in this sample suggested the presence of a secondary varzea forest on this location.

All late succession varzea forest samples showed different Shannon-Weiner diversity index values (Fig. 3), with MQ 16(2) and MQ 32(2) exhibiting the smallest values from all the samples (Fig. 3). MQ 17 (2) had a value of $\mathrm{H}=2.64$, which was the greatest value found. All primary succession varzea forest samples also showed different values (Fig. 3).

\section{Discussion}

The pollen record described from the Madeira River based on the samples described here showed a forest mosaic with different varzea forest types. According to Wittmann et al. (2010), this type of mosaic in flooded forests originates as a result of erosion and deposition processes opening new areas for colonization in these environments.

Swamp vegetation, including chavascal and lacustrine varzea forest, is difficult to differentiate based on the pollen record, because different pollen types commonly occur in similar frequencies, as it is the case of Araceae, Cyperaceae and Poaceae (Absy et al. 2014). In addition, in the current vegetation, herbaceous beyond that are very abundant, the characteristic species of both environments are mainly Polygonaceae of the Symmeria genus and Myrtaceae of the genera Eugenia and Calyptranthes (Wittmann et al. 2004; Wittmann et al. 2010). MQ 7(2) and MQ 42(1) showed the assemblage typical of a primary succession varzea forest and they were both similar to samples taken from chavascal and lacustrine varzea forest. This similarity could be explained by the frequent occurrence of the families Cyperaceae, Poaceae and Polygonaceae in chavascal, lacustrine varzea forest and primary succession varzea forest (Junk \& Piedade 1997). Another problem, the genus Alchornea occurs in three forest types. One possible criterion for differentiating these vegetations that would species Alchornea discolor occurs in varzea forest of lake and chavascal, while Alchornea castaneifolia occurs in primary succession varzea forest (Wittmann et al. 2010). However, it was not possible to differentiate the pollen of these species, raising the need for additional criteria. Swamps and lakes have high concentrations of Cyperaceae (Absy et al. 2014), among other types of pollen, whereas primary stages of varzea forest are characterized by high frequencies of Poaceae pollen (Wittmann et al. 2010). This could be used to differentiate between lacustrine varzea forest and primary succession varzea forest. Cluster analysis showed these differences by placing those samples belonging to lacustrine varzea forest or chavascal into a different group than those belonging to primary succession varzea forests, although these two groups were clustered together (Fig. 2).

The beginning of the stratification process typical of late secondary succession forests could be observed in sample MQ 17(2), as a result of the presence of Moraceae, Pithecellobium, and Sapium in the upper stratum and Alchornea, Melastomataceae, and Solanaceae in the lower stratum. In addition, MQ 17(2) also showed the highest Shannon-Weiner diversity index typical of communities in intermediate succession stages (Connell 1978).

Environmental diversity and plant species richness and diversity in varzea forests are known to correlate with the height and duration of flooding periods, age of plant communities, dominant channel patterns, morphodynamics, and complexity of the environmental mosaic of the floodplain (Wittmann et al. 2004; Latrubesse 2012). Late succession forests often present shortest height and duration of floods of all lowland varzea forests, they are also older (Wittmann et al. 2010); therefore, they show the highest levels of species richness and diversity. Thus, samples belonging to late succession varzea forests were quite different from each other, which cluster analysis showed by separating the different groups at different heights.

Previous research has also shown that a small number of species, even a single species, tend to dominate the vegetation in large tropical forest areas (Hart et al. 1989). Approximately 227 hyperdominant species are currently known from the Amazon, and 26 of them are native to the varzea forest (Steege et al. 2013). Therefore, species may occur at different ratios even compared to late successional stages, due to the occurrence of different dominant species.

Samples MQ 16(2) and MQ 32(2) showed the smallest Shannon-Weiner diversity indices. The lithostratigraphic unit from which MQ 16(2) was collected showed the characteristics of a channel. Thus, the pollen grains found in the sample are possibly a result of river transport, also explaining the low diversity values found here. Similarly, MQ 32(2) was collected from a point bar and scroll bar sequence, indicating that these pollen grains could have also been transported to this location.

Previous palynological analyses have shown that changes in savannah and forest vegetation occurred in the southern Amazon areas during the last glacial period (Absy \& Hammen 1976; Hammen \& Absy 1994; Mayle et al. 2000; Burbridge et al. 2004). Furthermore, the geological record of fluvial sediments indicates the occurrence of a strongly seasonal climate; however, high levels of sedimentation in the fluvial strip, with high water flow during floods during the Middle Pleniglacial and the initial period of the Last Glacial Maximum (LGM), and drier conditions might have occurred for much of the LGM (Latrubesse 2003). In addition, abundant fossil vertebrate fauna has been found from the Lujanense Mammal Age (Ranzy 2000; Nascimento 2008). The presence of varzea forest in LGM sediments in the Madeira River does not contradict the results found in previous studies. Research focused on the main tributaries of 
the Madeira River (Guaporé, Mamoré, Beni, and Madre de Diós rivers) show that they intersect at savannah areas (Ribera et al. 1994). Also, studies in potential areas of Bolivian vegetation (Navarro \& Ferreira 2004) show that Alchornea, Cecropia, Moraceae, Inga, and Sapium, which are found in the Madeira River, are also present in its tributaries, even in those located in savannah areas. These results suggest that a varzea forest surrounded by savannah vegetation in this region during the LGM is a possibility.

Pollen grains of Alnus, Podocarpus, Hedyosmum, and Ilex were found in samples from the late Middle Pleniglacial and early LGM (Fig. 5). These taxa have been suggested as indicators of mountain forest and humid conditions (Colinvaux et al. 1996; Bush et al. 2004; Freitas et al. 2013). However, Ilex species can be also found in varzea forests of the Amazonian lowlands (Wittmann et al. 2006; Wittmann et al. 2013), and certain Podocarpus species can occur in gallery forests of tree savannahs in central Brazil and in other types of savannah vegetation bordering the Amazon and Peruvian plains (Ledru et al. 2007). The pollen from these species often relies on anemophilous transport for dispersal (Behling et al. 2002; Freitas \& Carvalho 2012; Freitas et al. 2013), and there are records of Hedyosmum specimens collected near the town of Humaita, close to our study area (Chamberlain et al. 2014). Furthermore, all these species can easily reach the Amazonian lowlands, especially by river transport (Hammen \& Hooghiemstra 2000). Thus, is possible that these pollen types have been transported to the current location; however, an alternative explanation could involve a process wherein these taxa could have used the varzea to advance toward Amazon lowlands during LGM.
With the advance of the savannah in the southern Amazon during the last glacial period (Absy \& Hammen 1976; Hammen \& Absy 1994; Mayle et al. 2000; Burbridge et al. 2004), the varzea forest may have served as a refuge for species typical from non-flooded land. Reduced rainfall during the last glacial period (Hammen \& Absy 1994; Hooghiemstra \& Hammen 1998; Hammen \& Hooghiemstra 2000) possibly shortened the flood pulse period, producing shortened, albeit pronounced, flood period. These conditions, together with the decrease of the average annual flows, may have allowed certain dry land species to survive in the varzea forest, which may have served as a refuge for such species.

\section{Conclusion}

The paleovegetation of the Madeira River during the Late Quaternary was represented in the pollen record as a forest mosaic Our data showed the occurrence of primary succession varzea forest and lacustrine varzea forest or chavascal. These habitats showed some level of similarity; however, they may be differentiated based on the different frequencies of Cyperaceae and Poaceae pollen. Our results also show that those samples belonging to late succession varzea forests were different from each other, although those differences may be explained by the higher species richness and diversity typical from this type of forest, in addition to the existence of dominant species in the tropical forests.

Palynological and sedimentological studies conducted in the Madeira River region must be extended our understand-
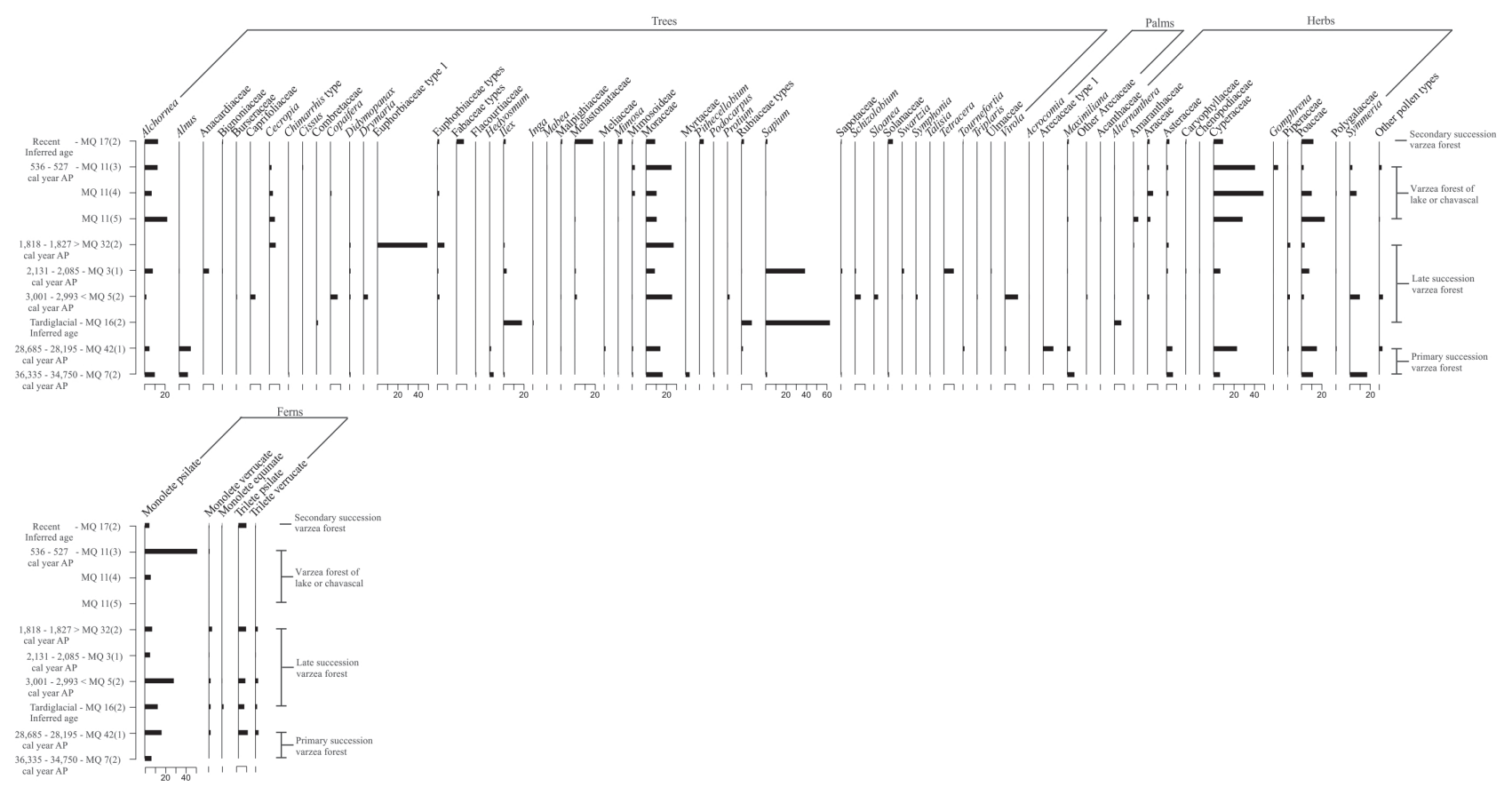

Figure 5: Percentage pollen diagrams of selected taxa from the central part of the Madeira River, Brazil. 
ing on how climate and environmental changes during the Late Quaternary in Amazonian varzea forests affected the vegetation of these areas.

\section{Acknowledgments}

The authors would like to thank the National Institute for Amazonian Research (Instituto Nacional de Pesquisas da Amazônia -INPA) and Biodiversity Coordination (Coordenação de Biodiversidade, CBIO) for their infrastructure support, which allowed us to conduct this study. We would also like to thank the National Council for Scientific and Technological Development (Conselho Nacional de Desenvolvimento Científico e Tecnológico, $\mathrm{CNPq}$ ) for the funding (Proc. 477127/2011-8) and the Brazilian Federal Agency for Support and Evaluation of Graduate Education (Coordenação de Aperfeiçoamento de Pessoal de Nível Superior, CAPES) for granting a scholarship.

We also thank Carlos D'Apolito (University of Birmingham, United Kingdom) and Marcos Gonçalves Ferreira (INPA) for their constant support in conducting this study.

\section{References}

Absy ML. 1979. A palynological study of Holocene sediments in the Amazon basin. PhD Thesis, University of Amsterdam., Netherlands. Absy ML. Cleef A. Fournier M. et al. 1991. Mise en evidence de quatre d'ouverture de la forêt dense dans le sudest de I' Amazonie au curs des 60000 dernières années. Premiére comparaison avee d’autres regions tropicales. Compte Rendus de I'Academie des Sciences 312: 673-678.

Absy ML. Cleef AM, D’Apolito C. da Silva MFF. 2014. Palynological differentiation of savanna types in Carajás, Brazil (southeastern Amazonia). Palynology 38: 78-89.

Absy ML, Hammen TVD. 1976. Some paleoecological data from Rondonia, southern part of the Amazon Basin. Acta Amazonica 6: 293-299.

Anhuf D, Ledru MP, Behling H, et al. 2006. Paleo-Environmental Change in Amazonian and African Rainforest during the LGM. Palaeogeography, Palaeoclimatology, Palaeoecology 239: 510-527.

Ayres JM. 1993. As Matas de Várzea do Mamirauá: Médio Rio Solimões. 3rd.edn. Belém, Sociedade Civil Mamirauá.

Behling H, Arz HW, Pätzold J, Wefer, G. 2002. Late Quaternary vegetational and climate dynamics in southeastern Brazil, inferences from marine cores GeoB 3229-2 and GeoB 3202-1. Palaeogeography, Palaeoclimatology, Palaeoecology 179: 227-243.

Burbridge RE, Mayle FE, Killenn T. 2004. Fifty-thousand-year vegetation and climate history of Noel Kempff Mercado National Park, Bolivian Amazon. Quaternary Research 61: 215-230.

Bush MB. 1994. Amazonian speciation: a necessarily complex model. Journal of Biogeography 21: 5-18.

Bush MB, De Oliveira PE, Miller MC, Moreno E, Colinvaux PA. 2004. Amazonian paleoecological histories: one hill, 3 watersheds. Palaeogeography, Palaeoclimatology, Palaeoecology 214: 359-393.

Chamberlain S, Boettiger C, Ram K, Barve V, Mcglinn D. 2014. Rgbif: Interface to the Global Biodiversity Information Facility API. R package version 0.7.0. https://github.com/ropensci/rgbif

Colinvaux PA, Irion G, Rasane ME, Bush MB, Nunes de Mello JAS. 2001. A paradigm to be discarded: Geological and paleoecological data falsify the HAFFER \& PRANCE refuge hypothesis of Amazonia speciation. Amazoniana 16: 609-646.

Colinvaux PA, de Oliveira PE, Moreno JE, Miller MC, Bush MB. 1996. A long pollen record from lowland Amazônia: forest and cooling in glacial times. Science 274: 85-88.
Connell JH. 1978. Diversity in Tropical Rain Forests and Coral Reefs. Science 199: 1302-1310.

Cowling SA, Maslin MA, Sykes MT. 2001. Paleovegetation simulations of lowland Amazonia and implications for neotropical allopatry and speciation. Quarternary Research 55: 140-149.

D’Apolito C, Absy ML, Latrubesse EM. 2013. The Hill of Six Lakes revisited: new data and re-evaluation of a key Pleistocene Amazon site. Quaternary Science Reviews 76: 140-155.

Klerk P, Joosten H. 2007. The difference between pollen types and plant taxa: a plea for clarity and scientific freedom. Quaternary Science Journal 56: 162-171.

DNPM - Departamento Nacional da Produção Mineral. 1978. Projeto RADAMBRASIL. Folha SB.20 Purus; geologia, geomorfologia, pedologia, vegetação e uso potencial da terra. Brasil, Rio de Janeiro.

Erdtman G. 1960. Pollen Morphology and Plant Taxonomy-Angiosperms. New York and London, Hafner Publishing Company.

Faegri G, Iversen J. 1966. Textbook of modern pollen analysis. Copenhagen, Scandinavian University Books.

Filizola N, Guyot JL. 2009. Suspended sediment yields in the Amazon basin: an assessment using the Brazilian national data set. Hydrological Processes 23: 3207-3215.

Freitas AG, Carvalho MA. 2012. Análise morfológica e inferências ecológicas de grãos de pólen e esporos (últimos $\sim 8.000$ Anos) da Lagoa da Ferradura, Armação dos Búzios, RJ, Brasil. Revista brasileira de paleontologia 15: 300-318.

Freitas AG, Carvalho MA, Mendonça CBF, Gonçalves-Esteves V. 2013. Pollen grains in quaternary sediments from the Campos Basin, state of Rio de Janeiro, Brazil. Acta Botanica Brasilica 27: 761-772.

Goulding M, Barthem R, Ferreira E. 2003. The Smithsonian Atlas of the Amazon. Washington e Londres, Smithsonian Books.

Haberle SG, Maslin MA. 1999. Late Quaternary vegetation and climate change in the Amazon basin based on a 50,000 year pollen record from the Amazon fan, ODP site 932. Quaternary Research 51: 27-38.

Hammen TVD, Absy ML. 1994. Amazonia during the last glacial. Palaeogeography, Palaeoclimatology, Palaeoecology 109: 247-261.

Hammen TVD, Duivenvoorden JF, Lips JM, Urrego LE, Espejo H. 1992. Late Quaternary of the middle Caqueta River area (Colombian Amazonia). Journal of Quaternary Science 7: 45-55.

Hammen TVD, Hooghiemstra H. 2000. Neogene and Quaternary history of vegetation, climate, and plant diversity in Amazonia. Quaternary Science Reviews 19: 725-742.

Hart TB, Hart JA, Murphy PG. 1989. Monodominant and Species-Rich Forests of the Humid Tropics: Causes for Their Co-Occurrence. The American Naturalist 133: 613-633.

Hooghiemstra H. 1984. Vegetational and Climatic History of the High Plain of Bogotá, Colombia: A Continuous Record of the Last 3.5 Million Years. Dissertationes Botanicae, 79: 1-138.

Hooghiemstra, H, Hammen, T. 1998. Neogene and Quaternary development of the neotropical rain forest: the forest refugia hypothesis, and a literature overview. Earth-science Reviews 44: 147-183.

Hoorn C. 1997. Palynology of the pleistocene glacial/interglacial cycles of the amazon fan (holes 940a, 944a, and 946a). In: Flood RD, Piper DJW, Klaus A, Peterson LC. (eds.) Proceedings of the Ocean Drilling Program, Scientific Results. Vol 155. p. 397-409.

Joosten H, Klerk P. 2002. What's in a name? Some thoughts on pollen classifications, identification, and nomenclature in Quaternary palynology. Review paleobotany and Palynology 122: 29-45.

Junk WJ, Piedade MTF. 1997. Plant Life in the Floodplain with Special Reference to Herbaceous Plants. In: Junk W. (ed.). The Central Amazon Floodplain: Ecology of a Pulsating System. Ecological Studies, vol. 126. Berlin, Springer-Verlag. p. 3-22.

Junk WJ, Piedade MTF, Schöngart J, Cohn-Haft M, Adeney M, Wittmann F. 2011. A classification of major naturally-occurring Amazonian lowland wetlands. Wetlands 31: 623-640.

Kummel B, Raupp D. 1965. Handbook of Paleontological Techniques. San Francisco, Freeman.

Latrubesse EM. 2002. Evidence of Quaternary palaeohydrological changes in middle Amazônia: the Aripuanã-Roosevelt and Jiparaná "fans." Zeitschrift für Geomorphologie 129: 61-72. 
Latrubesse E. 2003. The Late Quaternary paleohydrology of large SouthAmerican fluvial systems. In: Gregory K, Benito G. (eds.) Palaeohydrology: understanding global change. Hoboken, J. Wiley \& Sons. p. 193-212.

Latrubesse E. 2008. Patterns of Anabranching channels: the ultimate endmember adjustments of mega-rivers. Geomorphology 101: 130-145.

Latrubesse E. 2012. Amazon Lakes. In: Bengtsson L, Herschy R, Fairbridge R. (eds.) Lakes and Reservoirs. Berlin, Springer-Verlag. p. 13-26.

Latrubesse E, Stevaux JC, Sinha R. 2005. Tropical Rivers. Geomorphology 70: 137-206.

Ledru MP, Salatino MLF, Ceccantini G, Salatino A, Pinheiro F, Pintaud JC. 2007. Regional assessment of the impact of climatic change on the distribution of a tropical conifer in the lowlands of South America. Diversity and Distributions 13: 761-771

Louveaux J, Maurizio A, Vorwohl G. 1978. Methods of melissopalynology. Bee world 59: 139-157.

Mayle FE, Burbridge R, Killeen TJ. 2000. Millennial-Scale Dynamics of Southern Amazonian Rain Forests. Science 290: 2291-2294.

Nascimento ERD. 2008. Os xenarthra pilosa (megatheriidae), notoungulata (toxodontidae) e proboscidea (gomphotheriidae) da formação Rio Madeira, pleitoceno superior, Estado de Rondônia, Brasil. Msc Thesis, UFRGS, Brazil.

Navarro G, Ferreira W. 2004. Zonas de vegetación potencial de bolivia: una base para el análisis de vacíos de conservación. Revista boliviana de ecología y conservación ambiental 15: 1-40.

Prance GT. 1979. Notes on the vegetation of Amazonia III. The terminology of Amazonian forest types subject to inundation. Brittonia 3: 26-38.

Ranzy A. 2000. Paleoecologia da Amazônia: Megafauna do Pleistoceno. Florianópolis: Universidade Federal de Santa Catarina.

Reimer JP, Bard E, Bayliss A, et al. 2013. Intcal13 and Marine13 Radiocarbon Age Calibration Curves 0-50,000 Years Cal Bp. Radiocarbon 55: 1869-1887.

Ribera MO, Liberman M, Beck S, Moraes R. 1994. Mapa de vegetación y áreas protegidas de Bolivia. Escala 1:1.000.000. La Paz.
Roubik DW, Moreno JE. 1991. Pollen and Spores of Barro Colorado Island. Monographs in Systematic Botany. Panama, Missouri Botanical Garden.

Schöngart J, Piedade MTF, Worbes M. 2003. Successional differentiation in struture, floristic composition and wood increment of whitewater floodplain florest in Central Amazonia. In: Lieberei R, Bianchi HK, Boehm V, Reissdorf C. (eds.) German-Brazilian workshop on neotropical ecosystems-Achievements and Prospects of Cooperative Research. Hamburg, GKSS Geestacht. p. 589-606.

Steege H, Pitman NCA, Sabatier D, et al. 2013. Hyperdominance in the Amazonian Tree Flora. Science 342: 1243092.

Stockmar J. 1971. Tablets spores used in absolute pollen analysis. Pollen et Spores 13: 615-621.

Thomas MF. 2000. Late Quaternary environmental changes and the alluvial record in humid tropical environments. Quaternary International 72: 23-36.

Wittmann F, Anhuf D, Junk WJ. 2002. Tree species distribution and community structure of Central Amazonian varzea forests by remote sensing techniques. Journal of Tropical Ecology 18: 805-820.

Wittmann F, Householder E, Piedade MTF, et al. 2013. Habitat specifity, endemism and the neotropical distribution of Amazonian white-water floodplain trees. Ecography 36: 690-707.

Wittmann F, Junk WJ, Piedade MTF. 2004. The varzea forests in Amazonia: flooding and the highly dynamic geomorphology interact with natural forest succession. Forest Ecology and Management 196: 199-212.

Wittmann F, Schöngart J, De Brito JM, et al. 2010. Manual de árvores de varzea da Amazônia Central: taxonomia, ecologia e uso = Manual of trees from Central Amazonian varzea floodplains: taxonomy, ecology and use. Manaus, Editora Inpa.

Wittmann F, Schöngart J, Montero JC, et al. 2006. Tree species composition and diversity gradients in white-water forest across the Amazon basis. Journal of biogeography 33: 1334-1347.

Worbes M, Klinge H, Revilla JD, Martius C. 1992. On the dynamics, floristic subdivision and geographical distribution of varzea forests in central Amazonia. Journal of Vegetation Science 3: 553-564. 